\title{
ベイズ型スプライン回帰による 水位一流量曲線のフィッテング
}

\author{
高橋 啓 $^{1} \cdot$ 許士 達広 ${ }^{2} \cdot$ 石黒 真木夫 $^{3}$ \\ 1非会員 統計数理研究所特任助教＼cjkstart統計思考院（广 190-8562 東京都立川市緑町 10-3） \\ E-mail: k-taka@ism.ac.jp \\ 2 フェロー会員 北海学園大学教授 工学部 社会環境工学科（ $\bar{T} 064-0926$ 北海道札幌市中央区南 26 条西 11 丁目 1-1) \\ 3非会員 統計数理研究所特命教授 統計思考院（干 190-8562 東京都立川市緑町 10-3）
}

\begin{abstract}
本稿では, 水位流量曲線の推定にベイズ型スプライン回帰の活用を提案する。この曲線フィッティングは現場 において経験的に行われている，具体的には，流量について平方根をとり直線化することにより，区分線形的に 最小二乗法により推定する. しかし，この手法では作業者により推定される直線が異なる可能性がある。 また, 境界付近で直線が交差しない場合, 連続性を担保寸る客観的方法がなく, 作業者の工夫や判断により定めてい る. 提案手法では，一般化ベイズモデル選択によるパラメータ，区間数の決定により作業者の裁量の余地をなる べく排除する．また，スプラインの採用により，区分の曖昧さを排除し連続性を保証する。 そして，提案手法の 有効性を検証するために実データに適用した結果，良好なフィッティング曲線を一意に定めることができた。
\end{abstract}

Key Words: hydrology, discharge rating curve, Bayes estimation, spline regression

\section{1.はじめに}

水位一流量曲線（以下 $H-Q$ 曲線）は，連続的な観測 が不可能な河川，地点における流量を簡便に求めるた めに重要なものである。一般に，あらかじめ観測点を設 定し，おおよそ等間隔の観測日に浮子，横断測量，流速 計などから流量を実測する。この流量と水位の関係は, 前者を $x$ 軸, 後者を $y$ 軸にプロットすると, おおよそ 流量が水位の 2 乗となることが経験的に知られている. 多くの場合, 当該河川の流量が等流であること仮定し て, 得られた流量と水位のデータから, $H-Q$ 曲線を推 定することとなる1). 一般に小規模の単断面河道では単 純な一つの曲線となることが多い2). 一方, 大規模な河 川においては， $H-Q$ 曲線は，その複雑な断面や植生 に起因する複雑な曲線となる場合が多い。このような 複雑な断面における $H-Q$ 曲線の推定では, データを 区切り，区分的にカーブを推定することとなる3). 区分 化された曲線の具体的な推定方法は，二次曲線を非線 形最小二乗法により推定する方法（例えば Nemhauser et $\left.a l .{ }^{4)}\right)$ と, 流量について $\frac{1}{2}$ 乗することにより $H-\sqrt{Q}$ 直線とし, 最小二乗法を用いて回帰直線を推定する方 法がある。いずれにせよ， $H$ と $Q$ の関係が 1 対 1 対 応することが前提となる.

この区分的なカーブの推定には，作業的，幾何的側 面から多くの問題が指摘されている (例えば国土交通省 四国地方整備局 $\left.{ }^{6)}\right)$. 作業的側面からの問題として, 作 業者により描かれる $H-Q$ 曲線が異なるという点が挙
げられる．これは，実務において各区分曲線， $H-\sqrt{Q}$ とし直線を推定する際の採用基準が，個々の回帰直線 の相関係数が 0.8 (例えば倉光ら ${ }^{5)}$ ) といった曖昧な基 準を参考に運用されていることに起因すると考えられ る.この採用基準をなるべく統一化するために，ソフ トウェア7),8) も開発されているが，抜本的な解決には 至っていない, また, 描かれた曲線の幾何的側面から も問題が指摘されている.データを区分してそれぞれ の $H-\sqrt{Q}$ 曲線として最小二乗法で定めた場合, 隣り合 う二つの区間から推定された直線が平行に近い時には, その交点は当該区間において交点を持たないこととな る. $H$ と $Q$ の関係が 1 対 1 対応することが前提であ るため，このことはどこまでの区間をその曲線の適用 範囲にすべきが明確でないといった問題を生じさせ，作 業者の判断が必要となる。また, 流量観測が低水流量 以外は洪水時の高水流量観測が多いため, 中間領域に ついてデータ数が少なく, 推定が不安定になりやすい という問題点も挙げられる。これらの問題点を解消す るために, 実際の曲線を推定する際には各区分データ を一部分重複して使うなどして，交点を境界付近に定 めることが行われる。これを自動的かつ客観的に解消 することが望ましい.

$H-Q$ 曲線をべイズ推定により推定する手法はいくつ か提案されている (Arnason ${ }^{9)}$; Moyeed and Clarke ${ }^{10)}$; Reitan and Petersen- Øverleir 2008 ${ }^{11)}$ ). これらの研究 では, ベき乗の関数を仮定し, そのパラメータ推定に 
ベイズ推定を用いている。ただし，これらの研究では， 全ての水位（流量）においてそのパラメータは同一であ ると仮定している。しかし, 水位が異なれば河道断面も 大きく異なることは多く, 特に我が国ではこの仮定は 成立しづらい。この問題に対し，Reitan and PetersenØverleir (2009) ${ }^{12)}$ では，区分的かつ連続性を満たすス プライン回帰モデルを考案し，パラメータのベイズ推 定を行なっている. また, Hrafnkelsson et al. ${ }^{14)}$ は基本 となる非線形回帰とキュービック B-スプラインを組み 合わせ, $H-Q$ 曲線を推定している。 しかし, これらの 研究では, 区間数 $M$ の最適化についてほとんど触れて いない. また,「滑らかに変動する」という意味での平滑 化をモデルに取り込んでいないため，ある区間にデー タが全くない場合（No Data Problem）やあったと しても数が少ない場合に，物理法則にそぐわない曲線 が描かれる可能性を考慮できていない。中水位領域に ついてデータ数が少ない我が国の観測では，このモデ ルの素直な適用では問題が生じる可能性がある.

本稿では, 水位流量曲線 ( $H-Q$ 曲線) の推定に, これ らの問題点を克服可能なベイズ型スプライン回帰を用 いる方法を提案する. 具体的には, 次の手順で推定を行 なう。.まず，水位について $\frac{1}{2}$ 乗することにより $H-\sqrt{Q}$ 直線とし，この直線を一様区分線形，つまり折れ線と して推定する.ある区間にデータが一つも存在しない 場合，一般的なスプライン回帰では求めることができ ないが，回帰係数に対して滑らかに変動するという事 前情報を用いたベイズ型回帰を用いる。また，作業者 による推定結果の違いを防ぐために, ABIC, EIC 最小 化基準を内包した一般化ベイズモデル選択による区間 数 $M$ の決定を行なう. $\mathrm{ABIC}$ はベイズ型情報量基準の 一種であり，事前情報に相当する事前分布のパラメー タ (ハイパー・パラメータ) に対するモデル選択の基準 となる. EIC は最尤推定量以外にも適用可能な情報量 基準であり, 最大事後確率推定としてパラメータが選 ばれる今回のモデルにも適用可能な情報量基準である.

本稿の次章以降の構成は次のとおりである。まず 2 章において, 既存の $H-Q$ 曲線推定の手法とその問題 点について詳しく述べる. 次に 3 章において, 本研究 で用いるベイズ型スプライン回帰について，その定式 化からモデル選択までの具体的な手法を示す. 4 章で は, 3 章で提案された手法を, 実際の河川のデー夕に適 用する. 最後に 5 章では, 本稿の結論と, 今後の展望 について述べる。その他, 本論で詳細には述べていな い点については，付録にまとめる.

\section{2. $H-Q$ 曲線推定の既存手法とその問題点}

既存の $H-Q$ 曲線推定では, 流量 $Q$ を水位 $H$ の関 数であるとし，その関数のパラメータを最小二乗法に より求める. その多くが，2 次関数;

$$
Q=a(H+b)^{2}
$$

もしくは, 式 (1)を $\frac{1}{2}$ 乗した 1 次関数;

$$
\sqrt{Q}=a^{\prime} H+b^{\prime}
$$

を仮定し，パラメータを推定する。ここで， $a, b, a^{\prime}, b^{\prime}$ は推定対象のパラメータである。一次関数の場合には, 最小 2 乗法から一意に $a^{\prime}, b^{\prime}$ が求まり, それを用いて $a^{\prime}=\sqrt{a}, b^{\prime}=\sqrt{a} b$ として 2 次曲線が求める. また, 2 次関数でも推定対象となるパラメータ数が二つである ため, 最適化に Levenberg-Marquardt 法13)を用いてい る限り, 初期值をいくつか選い゙ば問題ない場合が多い. 最小 2 乗法を用いる推定は最尤推定を行っていること と等価であり, 最も尤もらしい解を得ていることとな る. 以上の議論は, 単一の曲線を当てはめるときのも のであり, これが複数考えられる場合にはその限りで はない.

複数の区間に分け， $H-Q$ 曲線を推定する場合を考え よう。一般的に河川は複数の異なる断面を持ち，また 河川敷には植生が存在するため, 複数の曲線を当ては めるというのは自然な考え方である。しかし，複数の 区間に分け，曲線を推定する場合には，単一の場合に は生起しない問題が生じる.

まず問題となるのが，標高方向にどこでデータを分け るのかという問題である. 図-1 は，後の適用で用いる， 北海道豊平川（藻岩）における水位-流量の観測デー夕 をプロットしたものである. 読者も, どの点からどの 点までを一つの区間として曲線を当てはめればよいの か迷われるだろう。次に問題となるのが，得られた曲 線をどの区間に適用するのかという問題である。最初 の問題を何らかの規則で定め曲線が当てはめられたと した場合でも，しばしば隣り合う直線の端部において 不連続が生じ, 連続化するために人為的な作業が必要 となることである，実務においては，各区分曲線，直 線を推定する際に, 各区分曲線, 直線の相関係数が 0.8 以上といった曖昧な基準を参考に運用されている ${ }^{1}$. そ のため, 担当者により, 描かれる曲線や区間の数が異 なるという裁量の余地がある.

\section{3. ベイズ型スプライン回帰を用いた提案}

本稿では, 既存手法で問題となっている点を解決する ため, ベイズ型 1 次スプライン回帰を用い, EIC 基準

\footnotetext{
${ }^{1} H-\sqrt{Q}$ とし全ての点を $H$ の順番で結べば，見かけ上相関係数 は 1.0 の折れ線が描ける.
} 


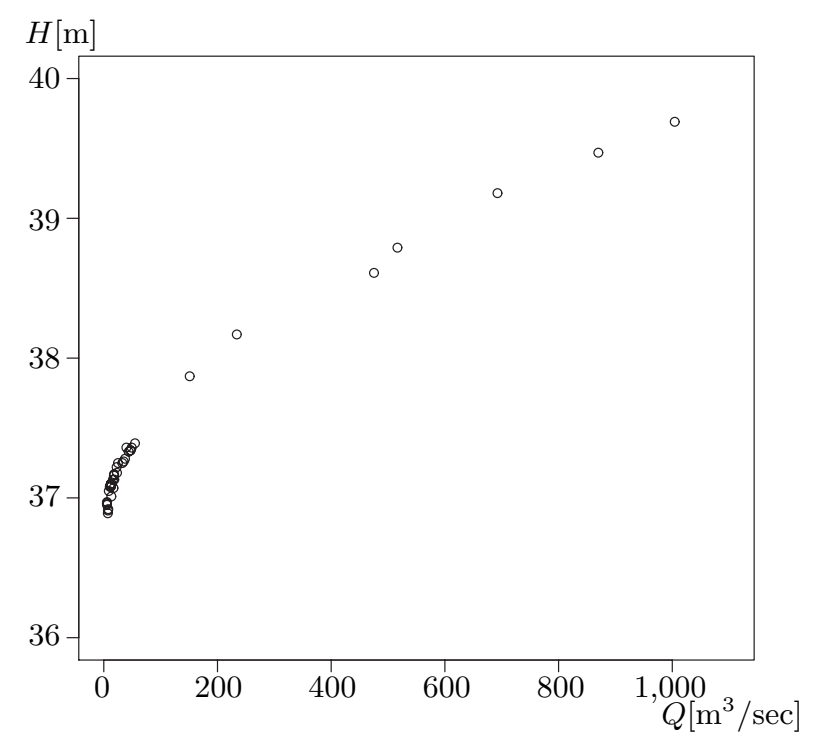

図-1 水位-流量の観測データ例

でそのノット数を決める手法を提案する. 1 次スプライ ンは所謂折れ線であり，既存手法で見られる曲線が不 連続になることやデータの分割といった問題は全く生 じない，また，直線の“滑らかさ”を決めるハイパーパ ラメータについては ABIC，ノット数については EIC という基準で統一的に曲線群を評価するため，担当者 により描かれる曲線や区間の数が異なるという問題点 も生じない.

ベイズ型スプライン回帰に関する研究として，一様 ノットを基本とする石黒・荒畑 ${ }^{15)}$ ，フリーノットを基本 とする Dimatteo et al. ${ }^{16)}$, Lang and Brezger ${ }^{17)}$, de Jonge and van Zantern ${ }^{18)}$ が挙げられる. 前者は, 本 研究と同様の枠組みを提案しているが，2 次のスプライ ンを用いている. 本研究のような場合には，2次のスプ ラインを用いると, 過適合と呼ばれる問題が生じてし まう。この点については，付録 I を参照されたい。ま た，後者では，フリーノットであるがゆえに，全ての データ点を繋いだような折れ線が描かれる可能性が高 く，今回のような場合にはそぐわない，また，これらの 研究ではノット数をどのように決定するべきかという ことには触れられていない. 本稿の回帰では， $H$ を説 明変数として $Q$ を説明するものとする. これは, 通常 $H$ については観測が容易であるが， $Q$ については，直 接観測が容易ではないためである.

\section{(1) 1 次スプライン回帰}

$N$ 対の水位と流量のデータ $\left(H_{i}, Q_{i}\right), i=1,2, \ldots, N$ があるとしよう。ここで，データは時系列ではなく水 位 $H$ の大きさの順に並んでいるものとする．このまま では, 曲線の当てはめとなってしまうため, $Q$ につい て $\frac{1}{2}$ 乗し, データを $\left(h_{i}, q_{i}\right), \quad i=1,2, \ldots, N$ とする.

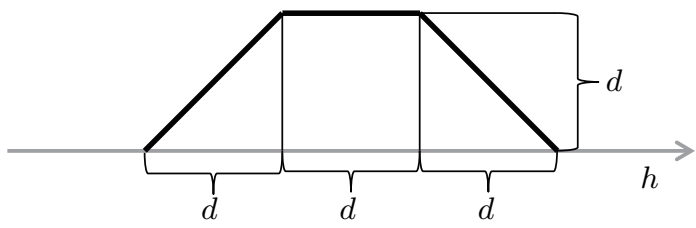

図-2 1 次 B-スプライン関数 $s_{j}(h)$

全ての $h_{i}$ が，区間 $(b, c]$ に存在すると仮定する.

等間隔ノット $\left\{t_{i}\right\}$ を持つ 1 次の B-スプライン;

$$
\begin{aligned}
\Omega\left(h_{i} \mid \boldsymbol{\alpha}\right) & =\sum_{j=1}^{M} \alpha_{j} s_{j}(h), \\
d & \equiv \frac{c-b}{M}
\end{aligned}
$$

を考えよう。ここで， $\alpha_{i}$ は $i$ 番目関数の重み, $s_{j}(h)$ は 対応する 1 次スプライン関数である. 寸ると, $i$ 番目の ノット $t_{i}$ は $d$ を用いて,

$$
t_{i}=b+d i \quad i=0,1, \ldots, M
$$

と表される.また, $s_{j}(h)$ を定義するために, 次の $2 つ$ の関数を定める. まず, $j(h)$ を区間 $(b, c]$ に対して,

$$
j(h)=j \text { if } h \in\left(t_{j-1}, t_{j}\right]
$$

と定義する.ここで， $\left(t_{j-1}, t_{j}\right]$ を $j$-区間と呼ぶ．さら に $d(j)$ を $j$-区間の中点として

$$
d(j)=\frac{t_{j-1}+t_{j}}{2}=b+d\left(j-\frac{1}{2}\right)
$$

を定義する．

具体的に, 1 次スプライン関数 $s_{j}(h)$ を定義しよう. $j(h), d(j)$ を用いて表記すると,

$$
\begin{aligned}
& s_{j}(h)= \begin{cases}\Psi(h-d(j-1)) & \text { if } j(h)=j-1 \\
\Phi(h-d(j)) & \text { if } j(h)=j \\
\Psi(d(j+1)-q) & \text { if } j(h)=j+1 \\
0 & \text { otherwise }\end{cases} \\
& \Phi(x)=d \quad-\frac{d}{2}<x \leq \frac{d}{2} \\
& \Psi(x)=x+\frac{d}{2} \quad-\frac{d}{2}<x \leq \frac{d}{2}
\end{aligned}
$$

となる。つまり, データ一つに対し高さ $d$ の台形を一 つの要素として対応させ，直線の近似を行なう（図-2 太線）。ここで, 推定対象となるのは, 各台形の高さ $d$ に掛け合わされる重み $\alpha_{j} j=1,2, \ldots, M$ である.こ の方法では, いくらスプラインを積み重ねても結果は 折れ線となる。折れ線は連続性が担保され，ある区間 には一つの直線しか存在しないため, 2 章で述べた既存 の非線形回帰のような問題は生起しない. 


\section{（2）スプライン回帰のパラメータ推定}

一般的に, スプライン回帰のパラメータ推定は, 尤 度関数;

$$
\begin{aligned}
& L\left(\boldsymbol{\alpha}, \sigma^{2}, M\right) \\
& \quad=\prod_{i=1}^{N} \frac{1}{\sqrt{2 \pi} \sigma} \exp \left(-\frac{1}{2 \sigma^{2}}\left(h_{i}-\sum_{j=1}^{M} \alpha_{j} s_{j}\left(h_{i}\right)\right)^{2}\right)
\end{aligned}
$$

を最大化することにより行われる。しかし，ノットを 細かく，すなわち $M$ を大きくすると，ある任意のノッ トにデータが存在しなくなり，これが続くと，パラメー タが不定となる恐れがある。今回適用する流量データ には，中水位領域にはデータが “落ちていない”ため， この問題は致命的である.

この問題を解決するために，石黒・荒畑が提案した ベイズ型の推定方法を拡張して用いる。ここでは， $M$ が十分大きい場合， $\alpha_{1}, \alpha_{2}, \ldots, \alpha_{M}$ の周期 1 の 2 階の 階差;

[DC1]

$$
\Delta_{1}^{2} \alpha_{j}=\alpha_{j}-2 \alpha_{j-1}+\alpha_{j-2} \quad j=1,2, \ldots, M
$$

が 0 近傍に対称に分布すると仮定しよう。これだけ では，データが疎らな区間で特定のデータにスプラ イン曲線（直線）が引っ張られる可能性が高いため, $\alpha_{1}, \alpha_{2}, \ldots, \alpha_{M}$ が周期 2 の 1 階の階差;

[DC2]

$$
\Delta_{2}^{1} \alpha_{j}=\alpha_{j}-\alpha_{j-2} \quad j=1,2, \ldots, M
$$

が 0 近傍に対称に分布するという条件を加える。この 条件は，経済時系列において周期性があるデータによ く適用されるもの（例えば，Kitagawa and Gersch ${ }^{19)}$, 北川 $\left.{ }^{20)}\right)$ であり，周期性を持たせることにより，より 安定した一本の直線に近い折れ線が描けるようになる. すると，この 2 つの条件 [DC1]，[DC2] を同時に課した 場合， $\boldsymbol{\alpha}$ に事前分布;

[PD1+2]

$$
\begin{aligned}
& f(\boldsymbol{\alpha} \mid u, s)=\left(\frac{u s}{2 \pi \sigma^{2}}\right)^{M} \\
& \cdot \exp \left(-\frac{u^{2}}{2 \sigma^{2}} \sum_{j=1}^{M}\left|\Delta_{1}^{2} \alpha_{j}\right|^{2}-\frac{s^{2}}{2 \sigma^{2}} \sum_{j=1}^{M}\left|\Delta_{2}^{1} \alpha_{j}\right|^{2}\right)
\end{aligned}
$$

を仮定することとなる。[DC1]，[DC2]をそれぞれ単独 で仮定した場合の事前分布 [PD1]，[PD2] は，それぞ れ 1 変量のガウス分布の確率密度関数を考えればよい. [PD1+2] を仮定した場合の推定值は，データが与えら
れた後の事後分布;

$$
\begin{gathered}
g(\boldsymbol{\alpha} \mid u, s) \propto L(\boldsymbol{\alpha}, \sigma, M) f(\boldsymbol{\alpha} \mid u, s) \\
=\frac{(u s)^{M}}{(\sqrt{2 \pi} \sigma)^{N+2 M}} \exp \left[-\frac{1}{2 \sigma^{2}}\left\{\sum_{i=1}^{N}\left(q_{i}-\sum_{j=1}^{M} \alpha_{j} s_{j}\left(h_{i}\right)\right)^{2}\right.\right. \\
\left.\left.\quad+u^{2} \sum_{j=1}^{M}\left|\Delta_{1}^{2} \alpha_{j}\right|^{2}+s^{2} \sum_{j=1}^{M}\left|\Delta_{2}^{1} \alpha_{j}\right|^{2}\right\}\right]
\end{gathered}
$$

の最頻值として得られる. 式 (15) では， $u, s$ を与件と すると $\boldsymbol{\alpha}$ は $\sigma$ と無関係に, $\exp$ の肩の部分

$$
\begin{aligned}
\eta(\boldsymbol{\alpha}, u, s) \equiv & \|\boldsymbol{h}-\boldsymbol{X} \boldsymbol{\alpha}\|^{2} \\
& +u^{2}\|\mathbf{0}-\boldsymbol{D} \boldsymbol{\alpha}\|^{2}+s^{2}\|\mathbf{0}-\boldsymbol{C} \boldsymbol{\alpha}\|^{2}
\end{aligned}
$$

を最小化することによって， $\boldsymbol{\alpha}$ は得られる。ここで， $\boldsymbol{X}$ は, $(i, j)$ 要素が $s_{j}\left(q_{i}\right)$ なる $N \times M$ 行列, $\mathbf{0}$ は $M$ 次 ゼロベクトル，D,C は，

$$
\begin{aligned}
\boldsymbol{D} & =\left[\begin{array}{rrrrrrr}
1 & -2 & 1 & 0 & \ldots & \ldots & 0 \\
0 & 1 & -2 & 1 & 0 & \ldots & 0 \\
\vdots & \ddots & \ddots & \ddots & \ddots & \ddots & \vdots \\
\vdots & & \ddots & \ddots & \ddots & \ddots & 0 \\
\vdots & & & \ddots & 1 & -2 & 1 \\
\vdots & & & & \ddots & 1 & -2 \\
0 & \ldots & \ldots & \ldots & \ldots & 0 & 1
\end{array}\right] \\
\boldsymbol{C} & =\left[\begin{array}{ccccccc}
1 & 0 & -1 & 0 & \ldots & \ldots & 0 \\
0 & 1 & 0 & -1 & 0 & \ldots & 0 \\
\vdots & \ddots & \ddots & \ddots & \ddots & \ddots & \vdots \\
\vdots & & \ddots & \ddots & \ddots & \ddots & 0 \\
\vdots & & & \ddots & 1 & 0 & -1 \\
\vdots & & & & \ddots & 1 & 0 \\
0 & \ldots & \ldots & \ldots & \ldots & 0 & 1
\end{array}\right]
\end{aligned}
$$

なる $M$ 次正方行列である. 石黒・荒畑では $\boldsymbol{D}$ につい て非零要素が一つ斜め下にずれているが，本研究では， 後述するように第一ノットをデータ区間外にずらして いるため，実質的に石黒・荒畑と同様の設定である。式 (16) は, 通常の最小二乗法に相当する項 $\|\boldsymbol{q}-\boldsymbol{X} \boldsymbol{\alpha}\|^{2}$ に罰則項 $\|\mathbf{0}-\boldsymbol{D} \boldsymbol{\alpha}\|^{2}$ 及び $\|\mathbf{0}-\boldsymbol{C} \boldsymbol{\alpha}\|^{2}$ を設け，その重 みをそれぞれ $u^{2}, s^{2}$ としていると捉えることもできる. なお， $\boldsymbol{\alpha}$ は $\sigma$ とは無関係に決まることに注意されたい. $u, s$ の決定と $\sigma$ の推定は，ベイズ型赤池情報量基 準 ${ }^{21)}$;

$$
\mathrm{ABIC}=-2 \log \int L(\boldsymbol{\alpha}, \sigma, M) f(\boldsymbol{\alpha}, u, s) \mathrm{d} \boldsymbol{\alpha}
$$

の最小化により行われる. 式 (16) により推定された $\boldsymbol{\alpha}$ を人余としよう。すると, 式 (19) に式 (15) を代入し, 多 
変数のガウス関数の積分公式を用い整理すると,

$$
\begin{aligned}
& \mathrm{ABIC}=(N+M) \log 2 \pi+(N+M) \log \sigma^{2} \\
&+ \frac{\|\boldsymbol{h}-\boldsymbol{X} \hat{\boldsymbol{\alpha}}\|^{2}+u^{2}\|\mathbf{0}-\boldsymbol{D} \hat{\boldsymbol{\alpha}}\|^{2}+s^{2}\|\mathbf{0}-\boldsymbol{C} \hat{\boldsymbol{\alpha}}\|^{2}}{\sigma^{2}} \\
&+\log \left\{\operatorname{det}\left(\boldsymbol{X}^{\mathrm{T}} \boldsymbol{X}+u^{2} \boldsymbol{D}^{\mathrm{T}} \boldsymbol{D}+s^{2} \boldsymbol{C}^{\mathrm{T}} \boldsymbol{C}\right)\right\}
\end{aligned}
$$

を得る. 式 $(20)$ を $\sigma^{2}$ について最小化の一階条件をと り, 整理することにより, $\sigma^{2}$ の推定值 $\hat{\sigma}^{2}$ は, 次のとお り求まる;

$$
\begin{aligned}
\hat{\sigma}^{2} & =\frac{1}{N+M}\left\{\|\boldsymbol{h}-\boldsymbol{X} \hat{\boldsymbol{\alpha}}\|^{2}\right. \\
& \left.+u^{2}\|\mathbf{0}-\boldsymbol{D} \hat{\boldsymbol{\alpha}}\|^{2}+s^{2}\|\mathbf{0}-\boldsymbol{C} \hat{\boldsymbol{\alpha}}\|^{2}\right\} .
\end{aligned}
$$

式 (21) を (19) に代入することにより, ABIC は, $u, s$ の関数として, 次のとおり求まる;

$$
\begin{aligned}
\operatorname{ABIC}(u, s) & =(N+M) \log 2 \pi \\
& +(N+M)+(N+M) \log \hat{\sigma}^{2} \\
& +\log \left\{\boldsymbol{X}^{\mathrm{T}} \boldsymbol{X}+u^{2} \boldsymbol{D}^{\mathrm{T}} \boldsymbol{D}+s^{2} \boldsymbol{C}^{\mathrm{T}} \boldsymbol{C}\right\} .
\end{aligned}
$$

式 $(22)$ では，最後の項に明示的に $M$ は現れていない が， $\boldsymbol{X}, \boldsymbol{D}, \boldsymbol{C}$ のランクとして $M$ は効いている. 実際の $\sigma^{2}$ の推定と $\mathrm{ABIC}$ の算出は, より効率的となるように 変形した上で行なわれている. $\sigma^{2}$ の推定と ABIC の算 出の詳細については, 付録 II を参照されたい.

次に $u, s$ の值の決定は, 次のような数值的最適化に より $\mathrm{ABIC}$ 最小化として行われる. 具体的な手法につ いては， $M$ を与件とした上で，グリッドサーチで決定 する. $u, s$ につての ABIC の単峰性は担保されてい ないため, 黄金分割法や共役勾配法等の勾配法（例え ば Nemhauser et al. $\left.{ }^{22)}\right)$ を用いることはできない.

\section{（3）一般化ベイズモデル選択}

最後にノット数 $M$ について, EIC 最小化により決 定される. $\mathrm{EIC}^{23)}$ は $\mathrm{AIC}$ を最尤推定以外にも用いる ことができるように拡張したものである．本モデルで は, $\hat{\boldsymbol{\alpha}}$ は最尤推定量ではなく事後分布最大化 (MAP) 推定量であるため, AIC をモデル選択基準として用い ることができない. データ $\boldsymbol{h}=\left\{h_{1}, h_{2}, \ldots, h_{N}\right\}, \boldsymbol{q}=$ $\left\{q_{1}, q_{2}, \ldots, q_{N}\right\}$ が与えられた場合, EIC は

$$
\begin{aligned}
\operatorname{EIC}(M) & =-2 \sum_{i=1}^{N} \log L\left(q_{i} \mid \hat{\boldsymbol{\alpha}}(\boldsymbol{h}, \boldsymbol{q})\right) \\
+ & \frac{2}{K} \sum_{k=1}^{K}\left\{\sum_{i=1}^{N} \log L\left(h_{i, k}^{\rho} \mid \hat{\boldsymbol{\alpha}}\left(\boldsymbol{h}_{k}^{\rho}, \boldsymbol{q}_{k}^{\rho}\right)\right)\right. \\
& \left.-\sum_{i=1}^{N} \log L\left(h_{i} \mid \hat{\boldsymbol{\alpha}}\left(\boldsymbol{h}_{k}^{\rho}, \boldsymbol{q}_{k}^{\rho}\right)\right)\right\}
\end{aligned}
$$

と表される. ここで， $\boldsymbol{h}_{k}^{\rho}=\left\{h_{1, k}^{\rho}, h_{2, k}^{\rho}, \ldots, h_{N, k}^{\rho}\right\}$ は，

$$
\rho(q)=\frac{1}{N} \sum_{i=1}^{N} \delta\left(h-h_{i}\right)
$$

という確率分布（生データそのものの分布）からサン プリングして得られる $k$ 番目シミュレーション・デー タである. $\delta(\cdot)$ は Dirac のデルタ関数である.また， $\boldsymbol{h}^{\rho}=\left\{h_{1}^{\rho}, h_{2}^{\rho}, \ldots, h_{n}^{\rho}\right\}$ は, $\boldsymbol{q}_{k}^{\rho}$ に対応した水位である.こ こで注意しなくてはならないのは，一般的に， $\hat{\boldsymbol{\alpha}}(\boldsymbol{h}, \boldsymbol{q}) \neq$ $\hat{\boldsymbol{\alpha}}\left(\boldsymbol{h}_{k}^{\rho}, \boldsymbol{q}_{k}^{\rho}\right)$ である. そのため, ハイパーパラメータの設 定を含め, $K$ 回の推定が $\mathrm{EIC}$ の計算には必要である. この $K$ の設定では，計算時間と精度とのトレードオフ を考慮する必要があり, データの数, 散らばり方に配 慮する必要がある. 式 $(23)$ にも明示的に $M$ は現れて いないが, $\hat{\boldsymbol{\alpha}}$ の要素数として効いている.

パラメータの推定からノット数の設定までの一連の流 れを図-3にまとめる。まず，ある与えられたパラメー 夕 $M^{l}, u^{l, N_{u}}, s^{l, N_{s}}$ のもとで, 事後分布最大化により解 析的に $\boldsymbol{\alpha}, \sigma$ を推定する. 次に $u, s$ についてグリッド サーチにより， ABIC 最小化に基づき決定する. 図-3 では，このグリッドサーチの箇所を $N_{h}=N_{i} \times N_{s}$ と しているが，実際には二次元グリッドで探索をしてい る. 推定, 設定されたパラメータ $\hat{\boldsymbol{\alpha}}, \hat{\sigma}, u, s$ のもとで, $\mathrm{EIC}$ を計算する. 最終的に $\mathrm{EIC}$ 最小化により $M$ を選 択する.

\section{4. 実データへの適用}

本章では，3 章で提案した手法を実際のデータに適用 する。具体的な場所としては，豊平川（藻岩）, 多摩川 (石原) への適用 ${ }^{2}$ 試みる. なお, 前者のデータは北 海道開発局から 2011 年 4 月 1 日-12 月 31 日のデータ, 後者のデータは関東地方整備局データの同じく 2011 年 4 月 1 日-2012 年 3 月 31 日のデータを用いている. 前 者のデータ数は $N=43$, 後者のデータ数は $N=76$ で ある、

以下全ての計算は，次のような設定のもとで行なう. $u, s$ のグリッドは, 事前の数值実験の結果より, それぞ れ $1 \times 0.95^{N_{u}}\left(N_{u}=0,1, \ldots, 99\right), 0.1 \times 0.95^{N_{s}}\left(N_{s}=\right.$ $0,1, \ldots, 99)$ とし, 計 10,000 格子上の探索とする.ま た，ブートストラップの回数については， $K=1,000$ 回とする.この回数で, EIC の值が表示されている有 効桁まで試行によらず有意であることは確認済みであ る. 最後に，ノットを刻む区間であるが，最初，最後の スプラインが端であることによる悪影響を及ぼすこと を考え, 最初, 最後についてはそれぞれ 1 ノット分を データ区間外とし，捨てノットとする.

推定の妥当性については, 既存のモデルと比較する ものとする。一般的には, 区分的線形回帰と比較する のが妥当であるが，客観性の面で問題があると考えら

\footnotetext{
2 今回の対象箇所では, 実際の曲線では不連続となるといった問 題点は生起していない.
} 


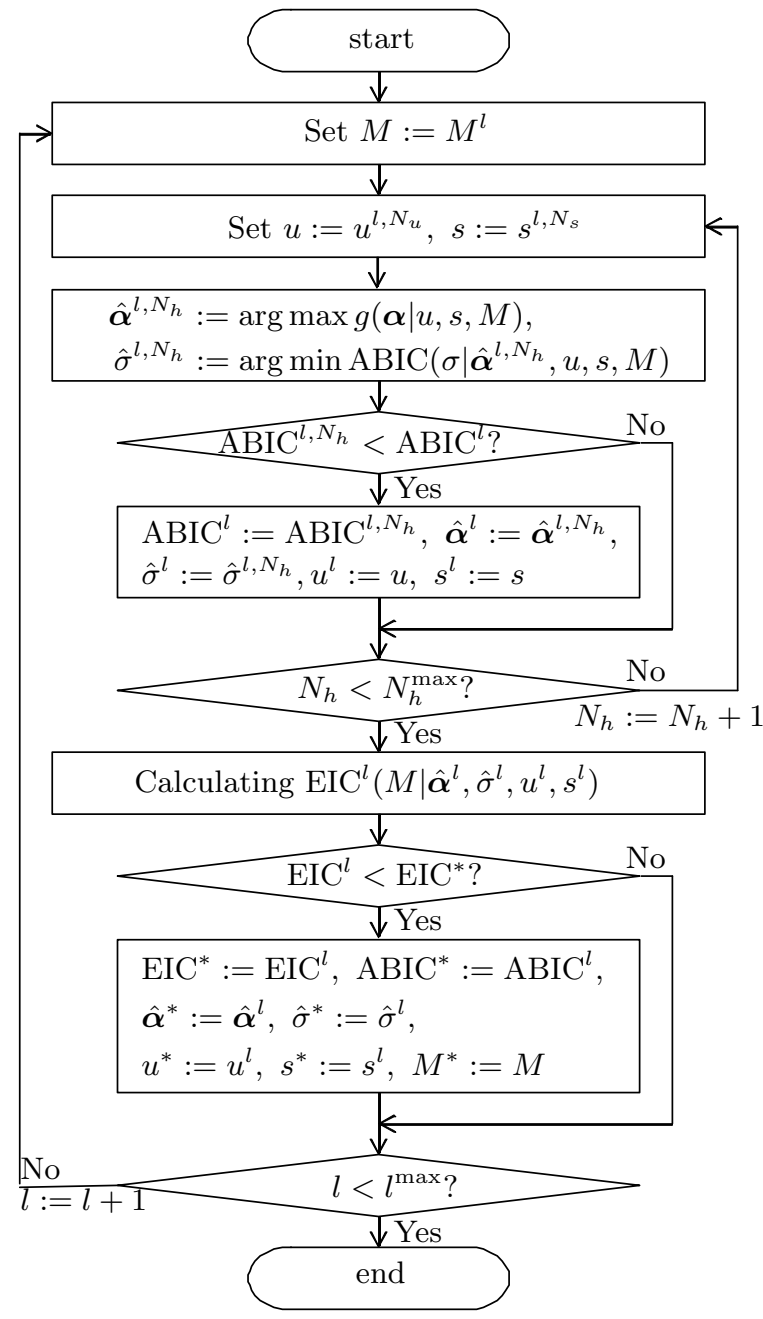

図-3 一般化ベイズモデル選択に基づく水位-流量曲線同定の 手順

れる. 作業者の手に委衫られる区分的線形回帰は，そ の解が作業者によりまちまちで一意に定まらないため, 客観的な比較が困難なためである。また，実際の区分的 線形回帰では，時期により細かく直線を分けている場 合もあるため，今回は比較対象とはしない，具体的な 比較対象は, Venetis のモデルを Markov chain Monte Carlo (MCMC) により推定している Arnason (Model 1), 通常のスプライン回帰を MCMC により推定してい る Reitan, T. and Petersen-Øverleir (2009) (Model 2), そしてそれらを複合した曲線を MCMCにより推定し ている Hrafnkelsson et al. (Model 3) とする. ただし, これらのモデルはエクスポネンシャル・カーブを直接 $Q-H$ 関係に適用しており，そのままでは単純に比較す ることができないため，あくまで，式 (2) の関係が成立 つと仮定し， $\sqrt{Q}-H$ 関係として直線もしくは折れ線の 推定を行うこととする。つまり，Model 1 では単純な 線形回帰, Model 2 では通常のスプライン回帰, Model
表-1 ノット数による $\mathrm{EIC}, \mathrm{ABIC}$ の変化（豊平川，藻岩）

\begin{tabular}{rrrccc}
\hline$M$ & \multicolumn{1}{c}{ EIC } & ABIC $^{*}$ & $\hat{\sigma}$ & $u$ & $s$ \\
\hline \hline 3 & 51.08 & 77.81 & 0.360 & 0.129 & 0.0599 \\
4 & 71.73 & 85.18 & 0.345 & 0.184 & 0.0488 \\
5 & 49.92 & 84.29 & 0.303 & 0.209 & 0.0397 \\
6 & 68.41 & 93.38 & 0.311 & 0.307 & 0.0397 \\
7 & 77.41 & 98.41 & 0.284 & 0.387 & 0.0377 \\
8 & 67.41 & 104.57 & 0.291 & 0.554 & 0.0368 \\
9 & 107.56 & 108.45 & 0.274 & 0.716 & 0.0358 \\
10 & 186.17 & 113.20 & 0.241 & 0.975 & 0.0349 \\
11 & 200.29 & 119.34 & 0.213 & 0.087 & 0.0244 \\
12 & 209.90 & 117.06 & 0.191 & 0.087 & 0.0215 \\
13 & 249.54 & 121.53 & 0.180 & 0.087 & 0.0204 \\
\hline
\end{tabular}

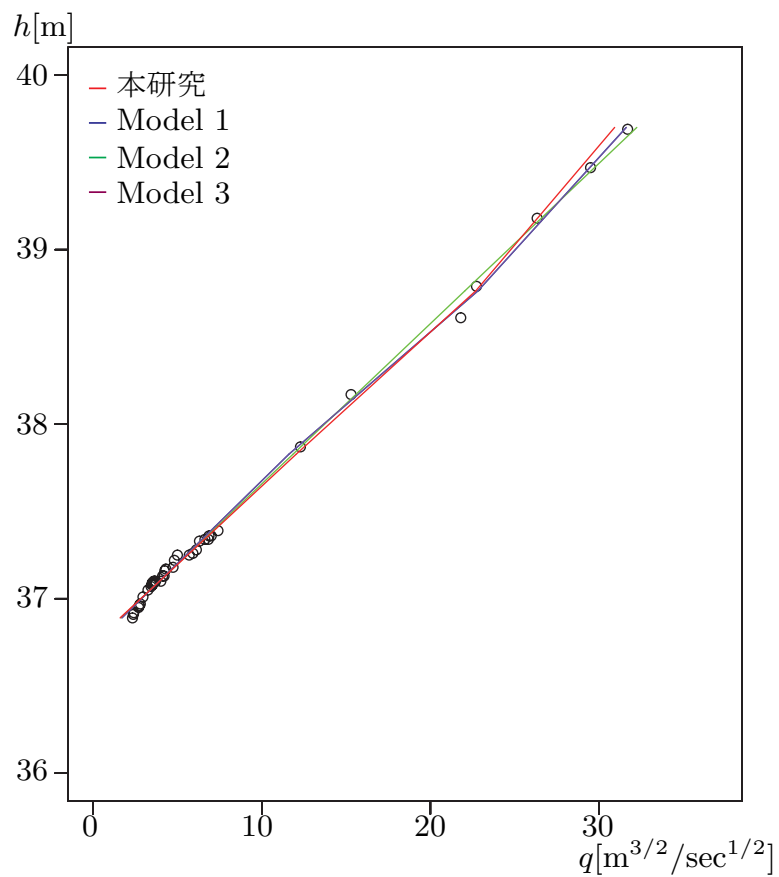

図-4 水位-流量曲線（豊平川，藻岩， $M=5$ )

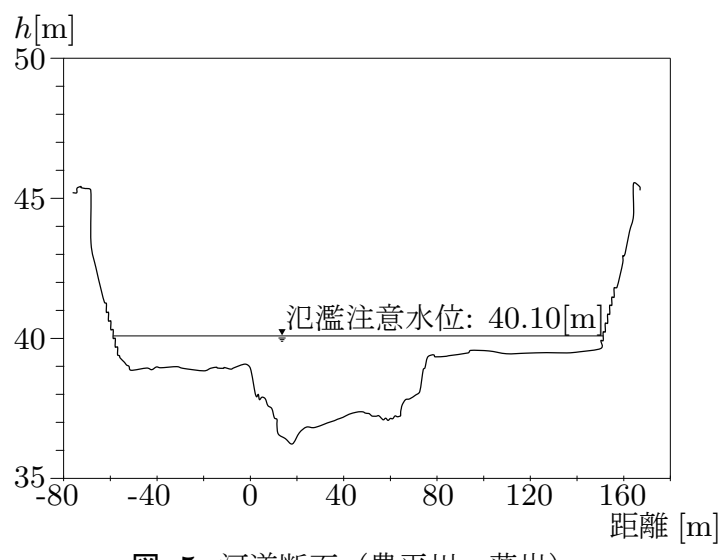

図-5 河道断面（豊平川，藻岩） 


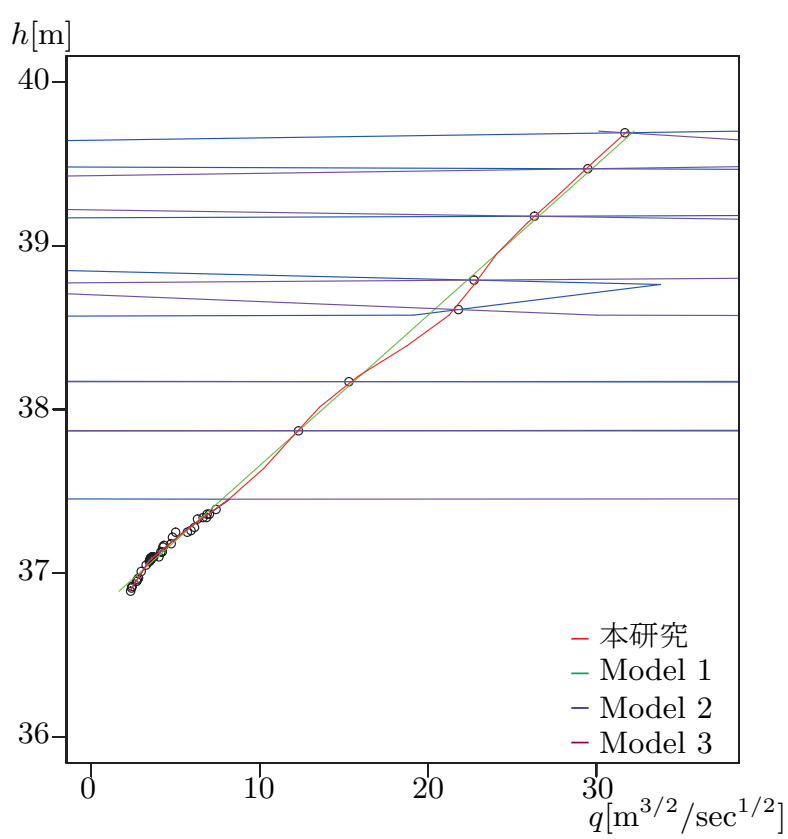

図-6 水位-流量曲線（豊平川, 藻岩, $M=17$ )

3 ではその組み合わせ ${ }^{3}$ となる．比較モデル 1-3 の詳細 な推定における設定については，付録 III を参照され たい.

\section{(1) 豊平川}

豊平川のデータのパラメータ推定結果および統計量 を表-1に示す。ここでは, EIC 最小化により, ノット 数 $M=5$ が選択される. MAP 推定されたハイパーパ ラメータによる $\mathrm{ABIC}$ の值 $\mathrm{ABIC}^{*}$ は, $M$ の増加に伴 い単調減少するが, EIC は $M=5$ で最小となるよう になっている. ただし， $M$ の増加に伴う $\mathrm{EIC}$ の変化 は複雑であり， $M=3,8$ も局所解となる。 このように 複雑となる理由は, スプライン回帰において $M$ が大 きいモデルが小さいモデルを内包しているわけではな いという点が挙げられる. 特に今回のデータは中水位 のデータが少ないため, 僅かなスプラインの位置のず れが全体の適合度に影響すると考えられる。 また，推 定された分散パラメータ $\hat{\sigma} も M$ の増加に伴い, ほぼ 減少している. 平滑化事前分布のパラメータ $u, s$ につ いては, $M$ の増加に伴い $M=1-10$ の範囲では単調減 少, 増加している.このパラメータ $u, s$ は值が小さい ほど事前分布の分散が小さいこととなるため，事前分 布として“効いている”こととなる，すなわち， $M$ の 増加に伴い $u$ より $s$ が相対的に制約が強く効いている ことを意味している.ただし， $M=11$ 以上はこの限 りではない。この領域では, $u, s$ が小さくなり, ほぼ 1

\footnotetext{
${ }^{3}$ Hrafnkelsson et al. では, $\sigma=$ const. とせず, 水位 $h_{i}$ に応じ て変化するようにしているが，今回は比較のため $\sigma=$ const. と する.
}

本の直線となる．才なわち， $M$ の増加分が $\mathrm{AIC}$ のパラ メータ数の罰則項と同様に EIC を増加させる.

ABIC，EIC により選択されたスプライン回帰直線 $(M=5)$ と $\left(h_{i}, q_{i}\right)$ のプロット (観測值)を図-4 に示す. 図-4では, データ数が少ない中水位でも安定的に直線 が描かれていることがわかる. 特に $q=20\left[\mathrm{~m}^{3 / 2} / \mathrm{sec}^{1 / 2}\right]$ 近傍に存在する回帰直線上から外れているデータにも 引っ張られることなく安定的な直線が描かれている。た だし, 選択された $M$ の数が小さく, 既存のモデル Model 1-3 との差はほとんどない.

今回と異なる条件 $(M=17)$ で，事前分布を含まな いスプライン回帰（Model 2,3）を実行した場合, 中 水位ノットの近傍にデータが比較的ないため, この部 分の係数が不安定となり, 鋸刃のような折れ線が描か れる（図-6）。ただし，これらの折れ線はほぼデータ 上を通過するものとなっており, 少ないデータに対し 過剩に適合する過適合と呼ばれる現象を起こしている. 一方, ベイズ型スプライン回帰では，このような現象 は起きず, データの近傍を通過しているものの, 安定 的な折れ線となる.

\section{(2) 多摩川}

多摩川のデータの推定結果を表-2 に示す．ここでは, EIC 最小化により，ノット数 $M=17$ が選択されてい る. 豊平川の場合と異なり, $\hat{\sigma}, u, s$ の単調性は一部保 たれていない，これは, 豊平川と比較しデータ数が多 くなったものの, 多くのデータがより低水位に集中し ておりある程度の分布があり，ノット間隔が変化する ことで低水位のデータへのフィッティングが変わりやす いためであると考えられる。

多摩川の推定されたスプライン直線 $(M=17)$ を図-7 に示寸，低水位時にはデータが二股に分かれているが, これは洪水前後による河道断面の違いに起因する ${ }^{4}$.

多摩川の場合には, ベイズ型スプライン回帰で EIC が最小となる条件 $(M=17)$ では, Model 2, 3 では直 線を描くことはできない，豊平川の場合には, Model 1, 3 でもなんとかそれらしい直線を描くことができたが, 多摩川の場合, ノット数が大きいため, 中水位 $(h=1.6-$ 2.7) において, 全くデータが存在せず, 式 (14)のよう な平滑化事前分布のような条件も存在しないため, ス プラインの係数が不定となる. Model 2, 3 では, 3 区 間連続でデータが存在しない場合, スプラインの係数 が不定となる. しかし, 本研究で提案したベイズ型ス プライン回帰では，そのような場合にも式 (14) が存在 するため, 図-7 のように安定的に折れ線を描くことが できる.

\footnotetext{
4 この点も興味深いが, 本研究の本質ではないため, 特に配慮は していない.
} 
表-2ノット数による $\mathrm{EIC}, \mathrm{ABIC}$ の変化（多摩川，石原）

\begin{tabular}{cccccc}
\hline$M$ & EIC & ABIC $^{*}$ & $\hat{\sigma}$ & $u$ & $s$ \\
\hline \hline 12 & 155.86 & 257.71 & 0.531 & 0.315 & 0.0513 \\
13 & 148.43 & 262.62 & 0.510 & 0.238 & 0.0475 \\
14 & 143.86 & 268.06 & 0.496 & 0.215 & 0.0463 \\
15 & 142.46 & 274.79 & 0.485 & 0.209 & 0.0452 \\
16 & 139.43 & 281.18 & 0.471 & 0.189 & 0.0429 \\
17 & 139.38 & 288.76 & 0.466 & 0.189 & 0.0429 \\
18 & 139.64 & 296.66 & 0.461 & 0.194 & 0.0429 \\
19 & 140.21 & 305.34 & 0.460 & 0.194 & 0.0418 \\
20 & 141.51 & 314.38 & 0.461 & 0.199 & 0.0418 \\
21 & 143.25 & 323.78 & 0.463 & 0.204 & 0.0429 \\
22 & 145.00 & 333.36 & 0.464 & 0.204 & 0.0429 \\
\hline
\end{tabular}

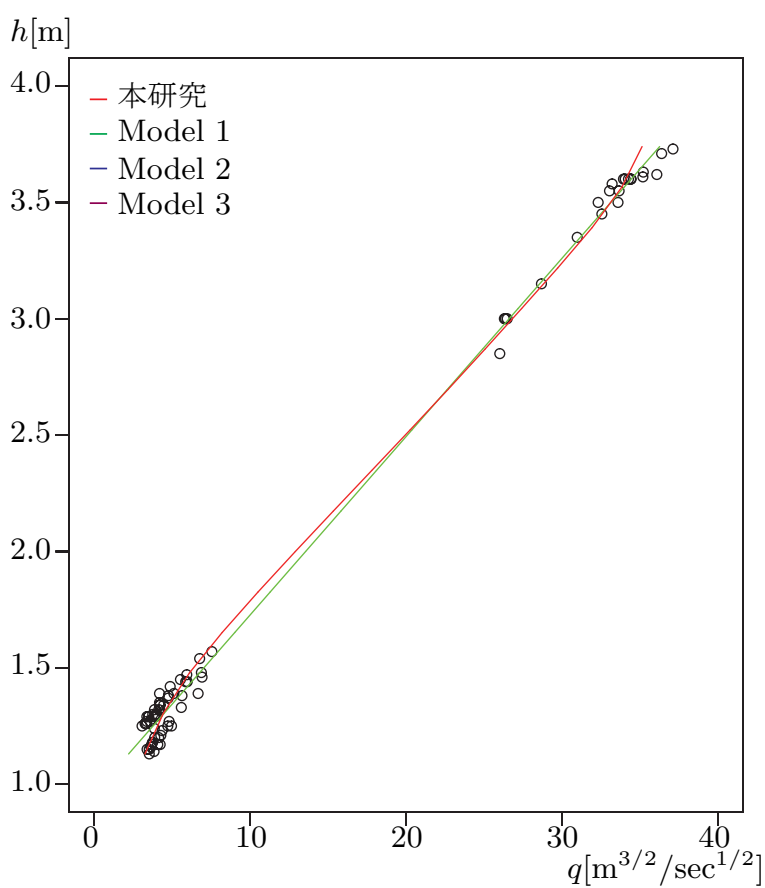

図-7 水位-流量曲線（多摩川，石原， $M=17$ )

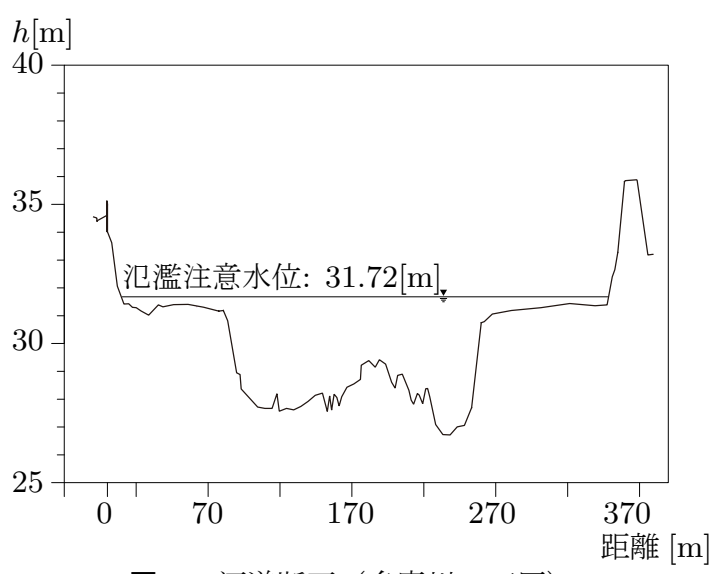

図-8 河道断面（多摩川，石原）

\section{5. おわりに}

本稿では, 水位流量曲線 ( $H-Q$ 曲線) の推定に, 従来 手法の問題点を克服可能なベイズ型スプライン回帰を 用いる方法を提案した。現状の実務で行なわれている 手法では，作業者により描かれる $H-Q$ 曲線が異なる という点，ある区間と隣り合う区間で直線が不連続に なり，直線が客観的な手法では求められないことが問 題点として挙げられていた。 そこで, 本稿では, ベイズ 型の 1 次スプライン回帰を用いた手法を提案した。こ の手法は，回帰直線が自動的に連続な折れ線となるた め, 回帰直線間の交点についての作業者による決定を 排除できる．また，折れ線を滑らかにするハイパーパ ラメータを導入し，このハイパーパラメータの決定に は ABIC，スプラインのノット数の決定には EIC 最小 化による決定手法を導入し，作業者による直線の決定 において裁量の余地をなるべく排除した。

次に，この提案された手法を実河川データに適用し， その有効性を確認した。具体的には，豊平川，多摩川 の場合に適用し，双方とも有効性を確認することがで きた，特に多摩川の場合には，従来のスプライン手法 では描くことができなかった折れ線を安定的に求める ことができた。

今後の展開としては, 観測方法の違いによる観測誤 差の大きさの違いをモデル化することが考えられる，流 速計による観測と浮子による観測では，その観測誤差 に大きな違いがあることが考えられ，これをモデル内 に取り込むことでより精緻かつ説明力のあるモデリン グが可能になる.

謝辞：この研究は, 情報・システム研究機構 統計数 理研究所 共同研究スタートアップ (2013-25) から発展 し，行われたものである。 また，水位，流量の実デー 夕及び河川断面の測量図を提供頂いた国土交通省北海 道開発局，関東地方整備局に感謝します。

\section{付録 I 2 次スプラインの適用}

$N$ 対のデータ $\left(H_{i}, Q_{i}\right), i=1,2, \ldots, N$ があるとしよ う.ここで, データは流量 $Q$ の大きさの順に並んでい るものとする，ただし，スプライン関数は，次のとお りとなる;

$$
\begin{array}{llrl}
\Phi(x)=-\frac{1}{d^{3}} x^{2}+\frac{3}{4 d} & \frac{d}{2}<x & \leq \frac{d}{2} \\
\Psi(x) & =\frac{1}{2 d^{3}}\left(x+\frac{d}{2}\right)^{2} & \frac{d}{2} & <x \leq \frac{d}{2} .
\end{array}
$$

推定方法は 1 次スプライン回帰と同様である. 


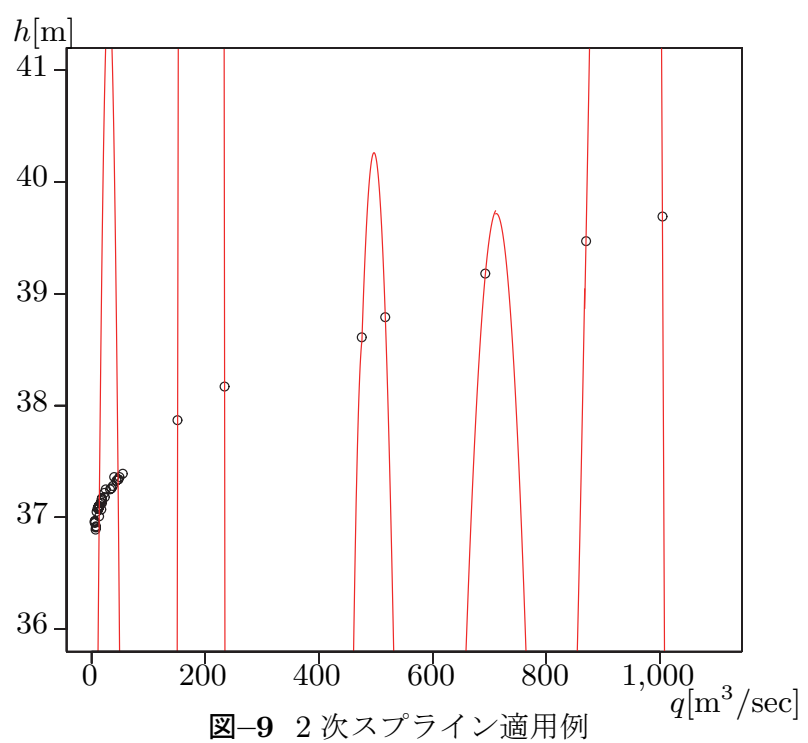

図-9 は，4 章で用いた豊平川のデータに 2 次スプ ライン回帰による曲線を重ねたものである ${ }^{5}$. 曲線は, データの近傍を通っているものの, 明らかに我々の想 像している曲線と異なり，過適合となっている。この ように, $H-Q$ 曲線の推定への 2 次スプライン回帰の適 用は極端な結果となりがちである。そのため, 本研究 では，2 次スプライン回帰用いないこととしている.

\section{付録 II 解析の詳細}

実際の数值解析では，効率よく解くために次のよう な変換をしている。まず，次式を，正規分布モデルの 平均值の最尤推定が最小 2 乗法と等価であることより,

$-2 \log L(\boldsymbol{q} \mid \boldsymbol{\alpha} ; \sigma, M) f(\boldsymbol{\alpha} \mid u, s)$

$\approx \frac{1}{\sigma^{2}}\|\boldsymbol{q}-\boldsymbol{X} \boldsymbol{\alpha}\|^{2}+\frac{u^{2}}{\sigma^{2}}\|\mathbf{0}-\boldsymbol{D} \boldsymbol{\alpha}\|^{2}+\frac{s^{2}}{\sigma^{2}}\|\mathbf{0}-\boldsymbol{C} \boldsymbol{\alpha}\|^{2}$ $=\frac{1}{\sigma^{2}}\left\|\left[\begin{array}{l}\boldsymbol{q} \\ \mathbf{0} \\ \mathbf{0}\end{array}\right]-\left[\begin{array}{c}\boldsymbol{X} \\ u \boldsymbol{D} \\ s \boldsymbol{C}\end{array}\right] \boldsymbol{\alpha}\right\|^{2}$

と変形できる。ここで，直交行列 $U$ を

$$
\boldsymbol{U}\left[\begin{array}{cc}
\boldsymbol{X} & \boldsymbol{q} \\
u \boldsymbol{D} & \mathbf{0} \\
s \boldsymbol{C} & \mathbf{0}
\end{array}\right] \equiv\left[\begin{array}{cc}
\boldsymbol{Y} & \boldsymbol{b} \\
\mathbf{0}^{T} & b
\end{array}\right]
$$

となり，なおかつ $\boldsymbol{Y}$ が上三角行列になるように選ぶ. ここで, $N \times(M+1)$ 行列 $[\boldsymbol{X}, \boldsymbol{q}]$ を上三角化した結果か ら $M+2$ 行目以降を取り除いた正方行列を $[\tilde{\boldsymbol{X}}, \tilde{\boldsymbol{q}}]$ とす る. また, $M \times(M+1)$ 行列 $[\boldsymbol{D}, \mathbf{0}]$ の下部 $M+1$ 行目に $\mathbf{0}^{\mathrm{T}}$ ベクトルを加えた正方行列を $[\tilde{D}, \tilde{\mathbf{0}}], M \times(M+1)$ 行列 $[\boldsymbol{C}, \mathbf{0}]$ の下部 $M+1$ 行目に $\mathbf{0}^{\mathrm{T}}$ ベクトルを加えた 正方行列を $[\tilde{\boldsymbol{C}}, \tilde{\mathbf{0}}]$ とする. すると, 式 (II.2)のように 5 ここでは極端な例を示すために, $Q, H$ を入替えて推定してい る.
上三角化することと, 次のように上三角化することは 等価である；

$$
\boldsymbol{U}\left[\begin{array}{cc}
\tilde{\boldsymbol{X}} & \tilde{\boldsymbol{q}} \\
u \tilde{\boldsymbol{D}} & \tilde{\mathbf{0}} \\
s \tilde{\boldsymbol{C}} & \tilde{\mathbf{0}}
\end{array}\right] \equiv\left[\begin{array}{cc}
\tilde{\boldsymbol{Y}} & \tilde{\boldsymbol{b}} \\
\tilde{\mathbf{0}}^{\mathrm{T}} & \tilde{b}
\end{array}\right] .
$$

ここで，計算量を抑えるために，uについて最適化する 際には $\tilde{\boldsymbol{X}}, \tilde{\boldsymbol{q}}, \tilde{\boldsymbol{D}}, \tilde{\boldsymbol{C}}$ を求めておき，式 (II.3) を上三角化 する.これらの上三角化の際には Householder 変換 ${ }^{24)}$ を活用し, 効率的に直交行列を見つける. 以上の変形 より，式 (II.2) は，直交行列 $\boldsymbol{U}$ により

$$
\begin{gathered}
\frac{1}{\sigma^{2}}\left\|\boldsymbol{U}\left[\begin{array}{c}
\boldsymbol{q} \\
\mathbf{0} \\
\mathbf{0}
\end{array}\right]-\boldsymbol{U}\left[\begin{array}{c}
\boldsymbol{X} \\
u \boldsymbol{D} \\
s \boldsymbol{C}
\end{array}\right] \boldsymbol{\alpha}\right\|^{2} \\
=\frac{1}{\sigma^{2}}\left\|\left[\begin{array}{c}
\tilde{\boldsymbol{b}} \\
\tilde{b}
\end{array}\right]-\left[\begin{array}{c}
\tilde{\boldsymbol{Y}} \\
\tilde{\mathbf{0}}^{T}
\end{array}\right] \boldsymbol{\alpha}\right\|^{2} \\
=\frac{1}{\sigma^{2}}\|\tilde{\boldsymbol{b}}-\tilde{\boldsymbol{Y}} \boldsymbol{\alpha}\|^{2}+\frac{\tilde{b}^{2}}{\sigma^{2}}
\end{gathered}
$$

となり, $\hat{\boldsymbol{\alpha}}$ は,

$$
\tilde{\boldsymbol{Y}}^{-1} \tilde{\boldsymbol{b}}
$$

の最初の $N$ 要素として求まる.

続いて，このままの枠組で ABIC の計算をする.まず,

$$
\eta \equiv \frac{(u s)^{M}}{(\sqrt{2 \pi} \sigma)^{N+2 M}}\left(\operatorname{det} \tilde{\boldsymbol{R}}^{\mathrm{T}} \tilde{\boldsymbol{R}}\right)^{1 / 2}
$$

とする。ここで， $\tilde{\boldsymbol{R}}$ は，

$$
R \equiv\left[\begin{array}{l}
D \\
C
\end{array}\right]
$$

なる $(2 M, M)$ 行列を Householder 変換により上三角化 したものの上 $(M, M)$ 成分の正方行列である.

すると $\mathrm{ABIC}$ は,

$\mathrm{ABIC}$

$$
\begin{aligned}
= & -2 \log \int \eta \exp \left\{-\frac{1}{2 \sigma^{2}}\|\tilde{\boldsymbol{b}}-\tilde{\boldsymbol{Y}} \boldsymbol{\alpha}\|^{2}-\frac{\tilde{b}^{2}}{2 \sigma^{2}}\right\} \mathrm{d} \boldsymbol{\alpha} \\
= & -2 \log \frac{\eta\left(2 \pi \sigma^{2}\right)^{M / 2}}{\left(\operatorname{det} \tilde{\boldsymbol{Y}}^{\mathrm{T}} \tilde{\boldsymbol{Y}}\right)^{1 / 2}}+\frac{\tilde{b}^{2}}{\sigma^{2}} \\
= & -2 \log \frac{\eta\left(2 \pi \sigma^{2}\right)^{M / 2}}{\prod_{j=1}^{M}\left\|\tilde{\boldsymbol{Y}}_{j j}\right\|}+\frac{\tilde{b}^{2}}{\sigma^{2}} \\
= & -2 \log \eta-M \log \left(2 \pi \sigma^{2}\right)+2 \sum_{j=1}^{M} \log \left\|\tilde{\boldsymbol{Y}}_{j j}\right\|+\frac{\tilde{b}^{2}}{\sigma^{2}} \\
= & (N+M) \log (2 \pi)+(N+M) \log \sigma^{2}-M \log \left(u^{2} s^{2}\right) \\
& -2 \sum_{j=1}^{M} \log \left\|\tilde{\boldsymbol{R}}_{j j}\right\|+2 \sum_{j=1}^{M} \log \left\|\tilde{\boldsymbol{Y}}_{j j}\right\|+\frac{\tilde{b}^{2}}{\sigma^{2}}(\mathrm{II} .8)
\end{aligned}
$$

となる. 1 行目から 2 行目の変形は, 多変量ガウス分布 の積分公式を用い， 2 行目から 3 行目は，上三角行列の 性質を用いている。ここで， $\tilde{\boldsymbol{Y}}_{j j}$ は， $\tilde{\boldsymbol{Y}}$ の $(j, j)$ 要素で 
ある. 式 (II.8) において, $\sigma^{2}$ の最小化の一階条件をと ると,

$$
\hat{\sigma}^{2}=\frac{\tilde{b}^{2}}{N+M}
$$

を得る。この解を式 (II.8) に代入し，整理すると，

$$
\begin{aligned}
\mathrm{ABIC}= & (N+M) \log (2 \pi)+(N+M) \log \frac{\tilde{b}^{2}}{N+M} \\
& +(N+M)-2 M \log (u s) \\
& -2 \sum_{j=1}^{M} \log \left\|\tilde{\boldsymbol{R}}_{j j}\right\|+2 \sum_{j=1}^{M} \log \left\|\tilde{\boldsymbol{Y}}_{j j}\right\| \quad(\text { II. } 10)
\end{aligned}
$$

を得る. 残された $u, s$ の数值的最適化, $M$ の決定は, 本文中のとおりである.

\section{付録 III＼cjkstart比較モデルにおける推定詳細}

本研究のモデルと比較するモデルでのパラメータ推 定には，MCMC を用いている. 具体的には, 統計解析 向けプログラミング言語 R と MCMC サンプラーであ る RStanを用いている。

$\alpha_{j} \forall j$ の事前分布には独立な平均 $M$, 分散 10 の正 規分布を， $\sigma$ の事前分布には， 0 から 10 までの無情報 (一様) 分布を採用する。また，全部で 20,000 回のサ ンプリングを行ない，そのうち初期の 10,000 回は事前 分布の影響があるとして採用しない. 最後に求められ た事後分布から点推定を行なう際には，異常值の影響 を少なくするために中央值を点推定量として採用して いる. 念のため, 分布としての収束がなされているか については, Gelman-Rubin test ${ }^{25)}$ の $\hat{R}$ が $1+0.05$ の 範囲に収束していることから確かめている.

\section{参考文献}

1) 木下武雄 : 流量観測の過去と未来, 河川流量観測の新時 代, Vol. 1, pp. 13-18, 2010.

2) 高崎忠勝, 大澤健二, 湊友洋，杉原大介：中小河川にお ける水位流量特性, 東京都土木技術支援 - 人材育成セン ター年報, pp. 117-122, 2012 .

3) Venetis, C.: A note on the estimation of the parameters in logarithmic stage-discharge relationships with estimation of their error, Bulletin of the International Association of Scientific Hydrology, Vol. 15, No. 2, pp. 105-111, 1970.

4) Choo, T. H., Park, S. K., Lee, S. J. and Oh, R. S.: Estimation of river discharge using mean velocity equation, KSCE Journal of Civil Engineering, Vol. 15, No. 5, pp. 927-938, 2011

5) 倉光大助, 大坂誠一, 遠藤哲雄, 中尾忠彦, 栗城稔: 水 文観測データ品質管理上の課題と今後の展開について平 成 21 年度河川情報シンポジウム講演集, 8 pages, 2009 .

6) 国土交通省四国地方整備局四国水文観測検討会 : 水文観 測の手引き（案） H-Q 曲線作成編, 2004.

7) 篠原努, 深見和彦, 吉谷純一, 大手方如 : HQ システム を用いた水位流量曲線の作成, 土木学会第 59 回年次学 術講演会講演概要集, pp. 127-128, 2004.
8) 独立行政法人士木研究所: 水位流量曲線式作成照查支援 システム操作マニュアル, Ver. 7.0.0, 2011.

9) Arnason, S.: Estimating nonlinear hydrological rating curves and discharge using the Bayesian approach, Masters thesis, Faculty of Engineering, University of Iceland, 2005.

10) Moyeed, R. and Clarke, R.: The use of Bayesian methods for fitting rating curves, with case studies, Advanced Water Resources, Vol. 28, No. 8, pp. 807$818,2005$.

11) Reitan, T. and Petersen- $\varnothing$ verleir, A.: Bayesian power-law regression with a location parameter, with applications for construction of discharge rating curves, Stochastic Environmental Research and Risk Assessment, Vol. 22, No. 3, pp. 351-365, 2008.

12) Reitan, T. and Petersen- Øverleir, A.: Bayesian methods for estimating multi-segment discharge rating curves, Stochastic Environmental Research and Risk Assessment, Vol. 23, No. 5, pp. 627-642, 2009.

13) Marquardt, D. W.: An algorithm for least-squares estimation of non-linear parameters, Journal of the Society of Industrial and Applied Mathematics, Vol. 11, No. 2, pp. 431-441, 1963.

14) Hrafnkelsson, B., Ingimarsson, K. M., Gardarsson, S. M. and Snorrason A.: Modeling discharge rating curves with Bayesian B-splines, Stochastic Environmental Research and Risk Assessment, Vol. 26, No. 1, pp. 1-20, 2012.

15) 石黒真木夫, 荒畑恵美子 : ベイズ型スプライン回帰, 統 計数理研究所彙報, Vol. 30, No. 1, pp. 29-35, 1982.

16) Dimatteo, I., Genovese C. R. and Kass R. E.: Bayesian curve-fitting with free-knot splines, Biometrika, Vol. 88, No. 4, pp. 1055-1071, 2001.

17) Lang, S. and Brezger, A.: Bayesian P-splines, Journal of Computational and Graphical Statistics, Vol. 13, No. 1, pp. 183-212, 2004.

18) de Jonge, R. and van Zanten, J. H.: Adaptive estimation of multivariate functions using conditionally Gaussian tensor-product spline priors, Electronic Journal of Statistics, Vol. 6, pp. 1984-2001, 2012.

19) Kitagawa, G. and Gersch, W.: A Smoothness priorsstate space modeling of time series with trend and seasonality, Journal of the American Statistical Association, Vol. 79, No. 386, pp. 378-389, 1984.

20) 北川源四郎 : 時系列の分解—プログラム DECOMP の 紹介—, 統計数理, Vol. 34, No. 2, pp. 255-271, 1986.

21) Akaike, H.: Likelihood and the Bayes procedure, Bayesian Statistics, eds. Bernardo, J. M., DeGroot, M. H., Lindley, D. V. and Smith, A. F. M., University Press, Valencia, Spain, pp. 143-166, 1980.

22) Nemhauser, G. L., Rinooy Kan, A. H. G. and Todd, M. J.: Optimization, Handbooks in Operations Research and Management Science, Vol. 1, 1989.

23) Ishiguro, M., Sakamoto, Y. and Kitagawa, G.: Bootstrapping log likelihood and EIC, an extension of AIC, Annuals of the Institute of Statistical Mathematics, Vol. 49, No. 3, pp. 411-434, 1997.

24) Householder, A. S.: Unitary triangularization of a nonsymmetric matrix, Journal of ACM, Vol. 5, No. 4, pp. 339-342, 1958.

25) Gelman, A. and Rubin, D. B.: Inference from iterative simulation using multiple sequences, Statistical Science, Vol. 7, No. 4, pp. 457-472, 1992.

(2015. 4. 9 受付) 


\section{FITTING OF DISCHARGE RATING CURVES USING BAYES SPLINE REGRESSIONS}

\section{Kei TAKAHASHI, Tatsuhiro KYOSHI and Makio ISHIGURO}

This paper proposes a fitting method for discharge rating curves using Bayes spline regression. At present, these curve-fittings are conducted empirically. Operators usually employ piece-wise least-squares method for estimating these curves with linearizing height-quantity relationship via taking the square root of flow quantity. However, this method has a serious fault; difference in the form of curves among operators. In our method, arbitrariness of operators is excluded with determination of the number of knots via the generalized model selection that minimizes ABIC and EIC. Furthermore, spline curves that sustain continuity evacuate conflict of lines near boundaries and guarantee continuity of discharge rating curve. To verify validity of our model, we adapt our method to the cross-sections of the Toyohira and the Tama rivers. As a result of the analysis, we can obtain favorable fitting curves in the both rivers. 